\title{
主題（I） 透析導入期の患者指導と透析中のヶアーについて
}

\section{Section 1}

\author{
司会前田貞 亮
}

1 血液透析中のケアーと導入期の患者指導—ルーム・リーダー制と受持ら看護婦制を通して一

甲南病院中央人工腎臟室

2 導入期患者指導スケジュールについて

3 導入期の患者指導について

東京慈恵会医科大学人工腎臟室

4 透析導入期の指導について 一食事指導以外の一

鳥取県立中央病院透析室

5 北里大学病院腎センターでの導入期患者の特徵

北里大学病院腎センター

6 種々の形の導入期透析看護について

関東労災病院人工腎室

7 透析導入期の患者指導について

国立王子病院警センター

8 透析導入期の患者指導 一反省と今後の指針一 川崎医科大学附属川踦病院人工腎膤室
豊崎 和美, 北村久美子, 徳岡 正子 平谷幸子，松崎 章子，植野八重子 藤関 恵子，渡津美智子，林本 保子

窪田滋子, 荒沢 陽子, 越石 敦子 鈴木 克典，土井 正勝，小松 茂 沼沢 良樹

山内 和子, 川崎 久子, 藤不佐和子 小暮 史恵，菊地 栄子，田崎 順子 大石キヌ子, 谷山繁彦, 井田宏和 中平博之，倉嶋 健二，太田孝史 福田 智之, 桑原 啓泰, 杉崎 弘章

坪野千恵子，平山 伴子，宾戸とし党 斉藤フサ子，藤原代紀子，岩波 久子 北原知

前田綟枝, 柿坂 成子, 田辺 智江 渡辺 京子，山下のり江，西尾 恵子 湯谷 豊子，山口美喜枝，草刈 敦子 下村 栄子，植田恵美子，池本 睦恵 平家 綾子, 山中 紀栄

五十嵐嘒子，山崎 幸子，野地 金子 知欦幸子, 松沢 孝子, 武 和子 米田 富子，青木 智子，丸茂 文昭 大久保充人, 桜井 健治, 鈴不潤 酒井紏, 小柴健

鈴木 水映, 真鍋美紀子, 満田 啓子 井上つぎ子, 村上 順子, 田上佐有美

横村 妙子, 吉岡 典, 丹治 郁子 辻口のり子, 原口真知子, 浅原宏美 塩野婿つ子，荒木 千鶴

林 百合子, 安井 久江, 鳥越 幸子 根木 香, 中村紀美子, 原敬子 那須美代子, 沖元伊津子, 山田 和代 植田 千春, 矢野 道代, 井上 喬之 
9 導入期透析の目的と透析ヶアーに対する提言

名古屋大学分院透析室 永田 量子, 関口志津子

内科 前田 憲志, 岸 常規 


\title{
血液透析中のケアーと導入期の患者指導
}

\section{ールームリーダー制と受け持ち看護婦制を通して一}

\author{
豊崎和美北村久美子徳岡正子平谷幸子松崎章子 \\ 植野八重子藤関恵子渡津美智子林本保子 \\ 甲南病院中央人工腎臟室
}

\section{〈要旨〉}

当院では、 $\mathbb{R} ・ \mathbb{L} ・$ 制と受け持ち看護婦制を併用し透析 中の安全管理と、患者個々の指導を行なっているが導入 期患者のみならず長期透析患者の受け持ら看護婦制には 問題点がまだ多く殘されている。我々はこれらの問題点 ととク組みながら，受け持ち䅨護婦制をくずすことなく よク良き看護の向上と，安全でしかも快適な透析が受け られるように努力している。

\section{はじめに}

慢性腎不全患者を長期生存へと導くためには，透析中 のケアーを充実させることは当然のことながら，不安定 な導入期患者の心理を考克，いかに指導し援助するかが， その患者の予後を左右寸ると思われる。特にこの時期に 蚛透析療法によってひさ牤こされる身体的苦痛から透析 を忌避したり，種々の制約による精配的苦痛から不幸な 転帰を招く危険性を以らんでいるため，緻密な心身の観 察が必要である。又，スタッフは導入期の患者に限らず 他の透析患者をも同時に安定した透析を施行しなければ ならず，透析中の患者のケアーも必要である。

当院ではこれらの条件を満し，患者が安全で快適な透 析が受けられるよう、インテンシブケアーの柱としてルー ムリ一ダ一制（R・L・制）を組み，さらに患者の個別指 喑を行ない精神的支えになることを目的として受讨持ら 看護婦制をとっている。

今回は，このR・L・制と受村持ら看護婦制を検討し報 告打。。

\section{看護体制}

我々の看護体制は図 1 の如くである。

\section{1. $\mathrm{R} \cdot \mathrm{L} \cdot$ 制 $^{2}$}

$\mathrm{R} \cdot \mathrm{L} \cdot$ ・制は透新中のケアーがスムーズに実施出来るよ らに組まれたすので，リーダーの下に 3 名のメンバーで 㨍成され，同時 24 床を 3 ルームに区分して透析究実施し ている。各ルームは毎朝リーダーを中心として，ショー トカンファンンスを行なった後，医師，テクニシャンと 共に，20〜30 分の合同カンファレンスを持ら患者個々の

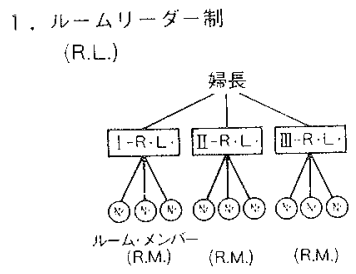

2. 受け持占看護婦制

3. 拘束制

緊急体制

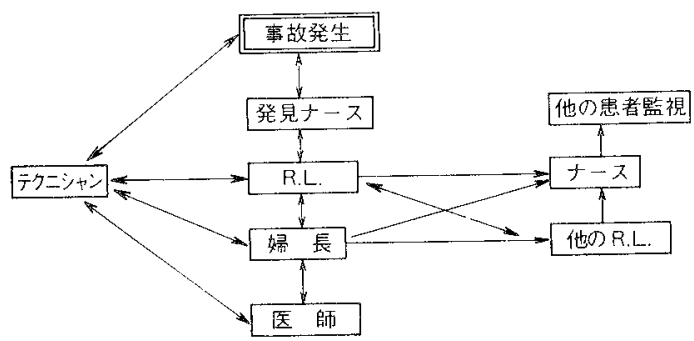

図 1 筹護体制

問題点や，機械側の問題点に関して各々の立場から検討 し業務計画をたてている。 R・L・はさらに患者急変時に は救急処置の実施，機械事故の場合はテクニシャンとの 連携プレー，医師，婦長への緊急報告，他への応援要請 の有無を判断し実行する。

\section{2. 受恃持看護婦制}

表1. は透析潦法が決定される時期から導入初期の指導 の概略である。透析を受けなければ生さられないことを， 知らされた患者と家族の動摇や恐怖，絶望感ははかり知 れないるのがあるが、こういった状態にある患者の気持 らを理解しスムーズに透析に尊入するため，透析滰法決 定の時期に受性持ら看護婦を決め，主治医と協力し家族 と本人に透析療法の必要性とその概略，安全性学説明し 過度の不安を与えないよらにしている。さらに歩行可能 な患者は実際透析空へ案内し，安全に透析を受けている 現場を見せ勇気つけている。 


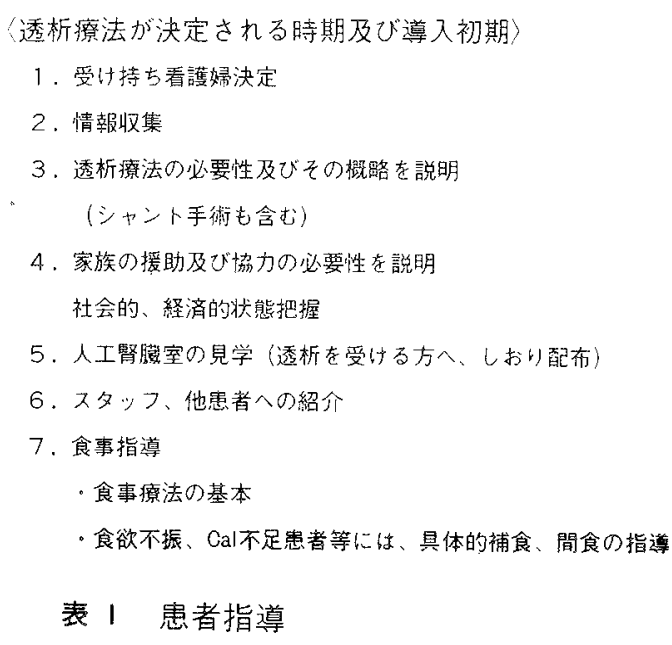

表 2 は導入中期，後期の受け持ち看護婦の役割である が，先つ外出外泊を行なう前に栄養士による食事指導を 受故させ, 日常の生活, 服薬の必要性, 緊急時の処置, 患者カードの携帯, 連絡方法など家族を含めて説明して いる。外出外泊は 1 食 1 泊加段階的に 2 泊 3 泊と寸寸 め, 自己管理能力をこの時期に養兄るよう援助する。社 会復帰にも積極的慟きかけ必要出ればケースワーカー への連絡，職場上司之医師の面接も行なっている。受け 持ち看護婦は患者の現況, 社会的家庭的問題, 身体的症 状等の把握をして個別指導に当るのは勿論で西るが，常 に患者とコミュニケーションをとり精神的支克になるこ とを目的としている。

受け持ち看護婦の長所と短所は表 3 の如くであるが, 長所としては患者に安心感をもた好身体的，精神的，社 会的状況を充分把握出来問題点の早期発見が可能であ り，そ机伴う合併症の予防に役立っていることなどが 考克られる。しかし，その反面，看護婦自身の性格，知 識レベルKより患者の反応が異なるとか，個人的感情が 出やすいなどの問題点も出ている。だが患者を受忛持つ ようになると今まで無関心であった看護婦も, 意欲的に 自己学習にとり組むようになり，朝のカンファレンスに も積極的炕発言し，チームナーシングに協力する姿勢が 見られるよらになるし，又，他の受け持ち看護婦のるつ

\section{1。食事指導}

透析食の基本実際

献立、調理上の工夫

外食、特殊食品の使用法

2. 生活指導

シャント管理 入浴方法

運動量について

服薬指導

3。自己管理の徹底

自己管理表の記入

合併症の危険性

4 . 外出。外泊

1 泊 1 食から段階的に2 泊、3泊とすすめる 緊急時の処置、連絡法

透析患者カードの携帯

5 。社会復帰への援助

職場の上司と面接、理解協力を求める

ケース・ワーカー

地域医療従事者との連絡

\section{表 2 導入中期・後期}

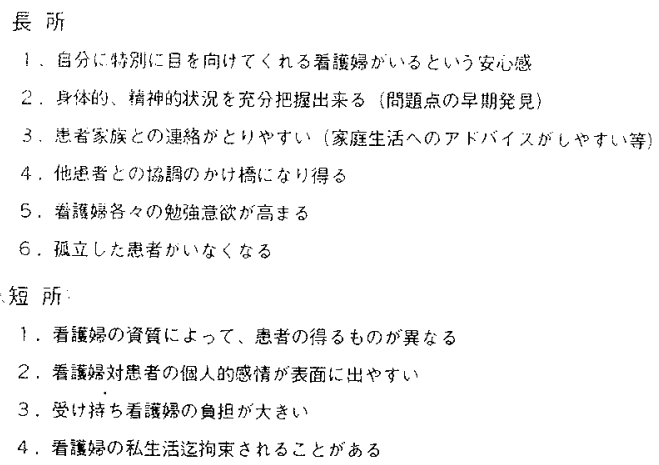

表 3 受け持ち䠗護䘲制

患者の悩みも共に考光，透析中に受け持ら看護婦では不 充分であったこれらの患者と接触して補い，より良い患 者指導を行な学るよらになってきている。 


\title{
導入期患者指導スケジュールについて
}

\author{
窪田滋子荒沢陽子越石敦子鈴木克典土井正勝 \\ 小松茂沼沢良樹山内和子* 川崎久子*藤木佐知子* \\ 小暮史恵*菊地栄子* 田崎順子*大石キ又子* 谷山繁彦* \\ 井田宏和* 中平博之* 倉嶋健二*太田孝史* 福田智之* \\ 桑原啓泰* 杉崎弘章* \\ 府中腎クリニック 調布病院腎センター
}

〈要是〉

透析導入期を更に 4 期間に分類して，患者指導を行っ ている。即ち

導入I期：入院日又はシャント作成日〜透析開始まで。 患者の不安感除去, 信頼関係形成を目的とし ている。

導入 II 期：透析開始日〜 2 週間。透析療法の必要性と無 症状透析の検討を目的としている。

導入III期：3週目〜 4 週目まで。透析療法に対する意識 の確認，社会復閳，外来透析への移行準備， 適性透析の設定を目的としている。

導入 IV 期：1 カ月目〜3カ月目まで。自己管理の徹底， 自立を目的としている。

以上，4期に分け，患者指導を行っているが，老人や 緊急透析から導入した症例では，スケジュール通り指導 がすすまず，各期を延長して導入期指導を行っている。

現在まで78名の透析患者を管理してきたが, 死亡率は 昭和 51 年 12 月 31 日現在，導入期死亡 40 名中 3 名， 7 . $5 \%$, 移行期死亡 46 名中 3 名， $6.5 \%$, 安定期 (1 年以上

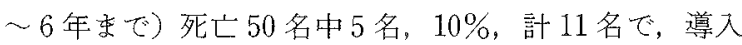
から最長 6 年までの死亡率は14.1\%だった。11名死亡中 6 名が導入期及び移行期死亡で，如何にこの時期を上手 に切り抜计るかが透析療法の成否を握っていると考光ら れる。

\section{1. 導入期の分類と患者管理について}

私達憤入期を，時期的に，便宜的に，4期に分類し ドクター，ナーステテニシャン，栄養士のチームが, 患者指導を行っている。即号，入院日又はシャント作成 日〜透析開始日までをI 期，透析開始日〜2週目までを II 期，開始 3 週目 4 週目までをIII期， 1 力月目 3 力 月目菓でを期としている。

各期の患者指導目的，力法については，表(1)(2)(3)(4)に 示す如く、ドクター，ナース，テクニシャン，栄㟤士の チームが，相互に連絡をとりながら各自の分担領域を，
(入院日又はシャント作成日より透析開始日まで)

\begin{tabular}{|c|c|c|}
\hline 当 & 的 & 法 \\
\hline トタタ .... & \multirow{4}{*}{$\begin{array}{l}\text { 怠者の不安感の } \\
\text { 解消 }\end{array}$} & $\begin{array}{l}\text { 1. 病態の説明 } \\
\text { 2. 邆析澺法の必要性の説明 } \\
\text { 3. 自己管理による社会復漫の可能性の説明 }\end{array}$ \\
\hline $\begin{array}{l}\text { 外来及U病槙 } \\
+ー ス\end{array}$ & & 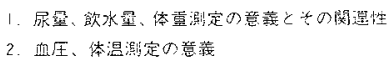 \\
\hline 透析室ナース & & $\begin{array}{l}\text { 1. スタッフの紹介 } \\
\text { 2. 䢪析室の䉂内 }\end{array}$ \\
\hline 嘎 士 & & 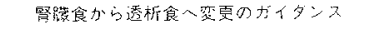 \\
\hline
\end{tabular}

表 1 導入I 期のオリエンテーション

(透析開始日より 2 深間)

\begin{tabular}{|c|c|c|}
\hline 担 & 的 & 法 \\
\hline 透析窑ナース & $\begin{array}{r}\text { 透析淲法の } \\
\text { 必要性 }\end{array}$ & 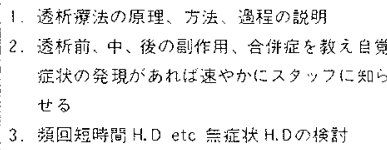 \\
\hline 病抰ナース & 钲症状透析 & $\begin{array}{l}\text { リ, 透新後の副作用発現 } \\
\text { 2. 食欲の減退に注意 }\end{array}$ \\
\hline 策琵 & & 透析食の必要性、食索基䧱老知る \\
\hline
\end{tabular}

表 2 導入 II 期のオリエンテーション

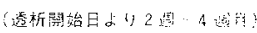

\begin{tabular}{|c|c|c|}
\hline 沘 & 的 & 法 \\
\hline \multirow[t]{2}{*}{ 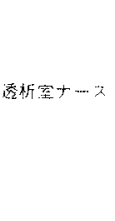 } & 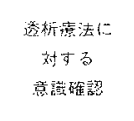 & 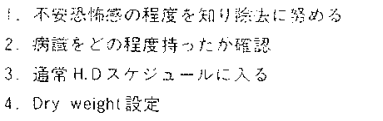 \\
\hline & 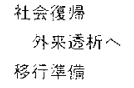 & 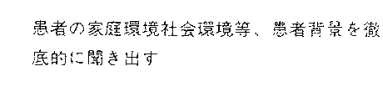 \\
\hline 透析 $7-4$ & 遂正透析の設䈯 & $\begin{array}{l}\text { 血流量 跟外沪過压 } \\
\text { ダイアライザー } \\
\text { ヘハリリン量の検討 }\end{array}$ \\
\hline
\end{tabular}

表 3 導入III 期のオリエンデーション 
責任を持って指導し，不足のところは，IV期汇補充する といら形式をとっている。そして試験外泊時の管理と自 己管理程度により，退院又は社会復帰させている。

(遭入!力月目・3力月自)

\begin{tabular}{|c|c|c|}
\hline 担 & 的 & 法 \\
\hline 透析キーム & \multirow[t]{2}{*}{$\begin{array}{l}\text { 自己管理の徵底 } \\
\text { 自立 }\end{array}$} & 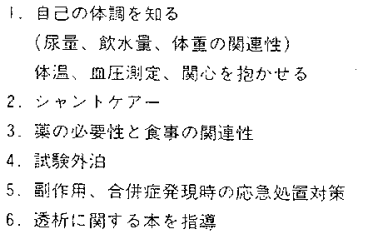 \\
\hline 党 盖 士 & & 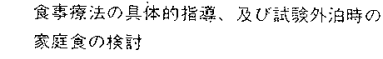 \\
\hline
\end{tabular}

表 4 導入 V V 期の才リエンテーション

2. 今後の導入期指導についての反省

導入期と安定期の透析中合併症を, 各々 1500 透析例, 2500 透析例を対象として比較すると，導入期は，悪心 $48 \%$ ，頭痛 $12 \%$ とD症候群に由来する副作用が多く，患 者に恐怖感を抱か心ない為にも，無症状透析が必要であ り今後の看護に役立てたい。

次に移行期から安定期の外来透析患者 47 名の自己管 理状況をアンケート形式で分析した，先ず社会，家庭環 境では，社会復帰している者が主婦業も含め $81 \%$ ，乙て いない者が $19 \%$ 。何か熱中出来るるのがあり，その時は 病気のことを㭱とんど忘れることが出来る者が $68 \%$ ，な
い者が 32\%で，常に病気のことが頭から離れず，注とん どが趣味を持たない者だった。生活中の楽しみでは，子 供，孫の成長，家族の団らんと答兄た者が $53 \%$ ，読書，

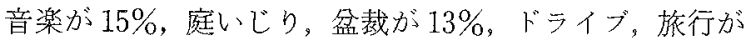
11\%，碁，麻雀，パチンコ等が $8 \%$ で，この中以も生き 甲斐となる様なものがない者があり，今後この様な生き 甲斐を持なない者を如何に看護指導していくか検討しな 汗ればならない。透析療法に対する不安感は，体力の減 退 $49 \%$ ，生命の危機感 $9 \%$, 将来の生活不安 $15 \%$ ，仕事 続行への可能性 $6 \%$ ，経済的 $4 \%$, その他 $17 \%$ で，今後 の透析療法の飛躍的な進歩, 腎移植の発展に希望を持ら, 社会保障を加味しながら看護指導をする必要性を痛感し た。医療環境，特に食事療法では，食欲が普通ないしそ れ以上と答光た者が $93 \%$ ，食事療法常に串施してい る者が $96 \%$ ，塩分量は指示通り $8 \mathrm{~g}$ 以下て制限している者か $97 \%$ ，食事外水分量も500 cc 以下で指示通り制限してい る者が $80 \%$ と，比較的良く管理されていたが，掑取カ口 リーでは, 1800 cal 以下 17\%, 1801 2000 cal 43\%, 2001

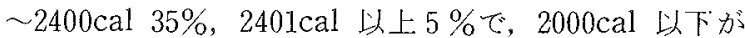
$60 \%$ と多く，今後間食の利用を含めカロり一不足を解消 していきたいと考えている。

次以内服薬では，時々忘れる者が $48 \%$ ，内容が判らな い者が $4 \%$ で，今後安定期以入ってからも指導を続けな ければならないと痛感している。

以上，導入期の患者指導と反省を含め報告した。 


\title{
導入期の患者指導について
}

\author{
坪野千恵子平山伴子穴戸としえ斉藤フサ子藤原代紀子 \\ 岩浪久子北原知 \\ 東京慈恵会医科大学人工腎臓室
}

\section{〈要旨〉}

より良い導入期指導を行なう目的で，患者のもつ不安 を具体的にアンケート調査し，興味ある結果をえた。透 析に対する不安としては，血液に対する恐怖・穿刺時疼 痛・慢性的な透析療法を続けることによる身体的ならび に社会的不安などが多く、これらは患者個々の背景の違 いから千差万別である。導入期の心理状態としては，半 数が容易に透析を受け入れたが，半数は透析を回避した いと考えた。すなわち未期蜸不全患者は，透析の必要性 を理解しながらも透析からの逃避を望む。しかし死に対 する恐怖から透析療法に移行した。透析療法を行ってみ ると症毒症状の消失, 透析の苦痛が以外に少いこと, 社 会復帰の可能性の増大などから不安は軽減した。以上よ ク導入に際しては，医師による透祈の必要性の説明のみ ならず,看護婦の立場から社会的心理的背景を的雄に把 握し不安の明確化を計ることが、よりょい導入期指導に なると考える。

はじめに

透析導入期の患者心，透析の必要性を理解しながらも 透析に対する不安感が強い。私達はより良い導入期指導 を行なら目的で，患者のるつ不安を具体的にアンケート 調査し興味する結果を党たので報告する。

対象占よび方法

対象は当院入院中の慢性腎不全で透析導入期の患者, 男性 7 名, 女性 3 名で年令は 28 才〜 60 才である。透析導 入時に以下のような項目についてアンヶート調査とイン タビューを行なった。(1)透析を必要と言われた時の心理 状態。（2）自分自身の中へ受け入れる因子となったもの。

(3)透析に伴亏不安をどら克服したか。(4)透析・機械につ いて知りたかった点。(5)透析室の環境についての印象・ 感じたこと。(6)透析中苦痛に感じたことについて。(7)社 会復帰についてどう考光るか。

\section{成績および考案}

アンケートの結果は表 1 4 K示したごとくである。す なわち透析に対する不安としては，血液に対寸る恐怖，穿 刺時の疼痛，慢性的な透析療法を続けることにより生ず る身体的ならびに社会的不安が多くみられた。これらは

(1) 透析を必要と言方 れた時の心理状態

\begin{tabular}{|l|l|}
\hline くるべききのがきた & 4 名 \\
\hline $\begin{array}{l}\text { 身体的苦痛から逃れ } \\
\text { たい }\end{array}$ & 1 名 \\
\hline 移植を考えた & 1 名 \\
\hline 将来への不安の增大 & 2 名 \\
\hline 抑压を感じた & 2 名 \\
\hline
\end{tabular}

(2) 自分自身の中へ受 け父れる因子とな ったもの

表|アンケートの結果

（3）透析に伴う不安をどう克服したか

\begin{tabular}{|l|r|}
\hline 仕方がない & 3 名 \\
\hline 透析を経験することにより & 3 名 \\
\hline これからの閔題である & 3 名 \\
\hline 透析者に話を聞いて & 1 名 \\
\hline
\end{tabular}

表 2 アンケートの結果

(4) 機械について知りたかった点

\begin{tabular}{|l|ll|}
\hline 身体が受ける影響への不安 & 4 & 名 \\
\hline 使用機械の構造・取り扱い & 2 & 名 \\
\hline
\end{tabular}

（5）透析室の嫴境についての印哀・感じたこと

\begin{tabular}{|l|rl|}
\hline $\begin{array}{l}\text { 多量の血腹が体外に出ていることに刘す } \\
\text { る不安 }\end{array}$ & 6 & 名 \\
\hline スタッフの働きかけによる安心感 & 3 & 名 \\
\hline 人間工場という印率 & 1 & 名 \\
\hline
\end{tabular}

表3アンケートの結果

患者の性別・年令・職業・家族的背景などの違いから千 差万別であることがわかる。 なた透析導入期の心理状態 としては，半数はくるべさるがきたとして容易に受け 入れたが，半数は透析を回避したいと考劣ている。しか し透析を経験することにより透析導入以前に考えていた より不安招よび苦痛は少いことが解り社会復帰に対する 意欲となっている。 
(6)透析中・苦痛に感じたこと

\begin{tabular}{|c|c|}
\hline 穿 刺時の痛 み & 3 名 \\
\hline 不均衡症候碓 & 4 名 \\
\hline 脣時間の同一体位 & 3 名 \\
\hline
\end{tabular}

(7) 社会復費についてどう考之ていますか

\begin{tabular}{|l|r|}
\hline 透析者问けの仕事があれば良いと思う & 1 名 \\
\hline 倳場への谷おくれがある & 1 名 \\
\hline 前と同じに㗢きたい & 5 名 \\
\hline 仕事につくか、習い事をしたい & 2 名 \\
\hline
\end{tabular}

表 4 アンケートの結果

末期腎不全患者は，透析の必要性を認めているにもか かわらず，透析に対する知識がないために不安が強く何 とか透析を回避できないものかと考完たが、しかし透析 を行ってみると疗毒症状の消失，透析の苦痛は思ったよ り軽いこと, 社会復帰への可能性が増強したことから透
析療法に対する不安は軽減した。以上の結果加ら透析導 入に際しては，医師による透析の必要性の説明のみなら ず看護婦の立場で指導することの重要性が認められた。

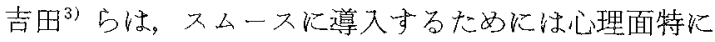
患者との信頼関係を強調し，Czaczkes らは患者の対応 には家族構成及び社会的立場の考慮を重視し，画一的な care では不十分であると報告しているが著者の結果に 扣いては，患者に導入期以前としては親近感を与兄ると 同時に透析に伴ら不安が何であるかを患者と共に明らか にしてゆくことが透析の必要性を早く且つ正しく理解さ やることとなり，結果的に社会復帰への大きな援助とな ると考える。すなわら導入期の患者指導として患者の社 会的心理的背景を的確に把握し不安の明確化を計ること によりより良い導入期指導がでさると考光る。

\section{文献}

1)Czaczkes, J. W., et al : Proceeding of the European Dialysis and Transplant Association. IX : 167, 1973

2)鈴木水映他：人工透析研究会誌 $9: 34,1976$

3)吉田公子：透析（IX），人工透析研究会編 1975 


\title{
透析導入期の指導について一食事指導以外の一
}

\author{
前田絹枝柿坂成子田辺智江渡辺京子山下のり江 \\ 西尾恵子湯谷豊子山口美喜枝草㺫敦子下村栄子 \\ 植田恵美子池本睦恵平家綾子山中紀栄 \\ 鳥取県立中央病院透析室
}

\section{〈要旨〉}

透析治療には患者自身の自覚と努力と認識が必要であ $\eta$ ，特に導入期の基礎知識をしつかり理解させることが 大切であります。そこで導入期の指導として,指導チェッ クリストを折り込んだ指導計画により、よい結果を得て います。

慢性疾患はすべて患者自身が治るらと努力しなくては 治療が成功しないと良く言われていますが，腎不全に拈 いても，自分の病気についてはっきりした認識を持たせ 透析とは，どらいうものかについて十分理解させること が大切でありま扵。当院に拈いても導入期の指導に表 1 のよらな指導チェックリストを使用し，各項目について 指導しチェックしてゆくようにしていましたが，どこか ら指導してゆ忛ばよいかの問題点があがってきました。

\begin{tabular}{|c|c|c|c|}
\hline & 指道 項 & 月曰と少任 & 僧 考 \\
\hline \multirow{2}{*}{ 督 } & 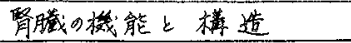 & & \\
\hline & 赘 不 全 & & \\
\hline \multirow[t]{3}{*}{ 水 } & 健康人の体液租成 & & \\
\hline & " 水分出缸 & & \\
\hline & 目的 & & \\
\hline \multirow[t]{2}{*}{ 人 } & 透析の原理反实際 & & \\
\hline & 透析 液 & & \\
\hline \multirow[t]{2}{*}{$I$} & ダイヤライザー & & \\
\hline & シャント & & \\
\hline \multirow[t]{2}{*}{ 督 } & 不均衡症候群 & & \\
\hline & 透析中の事故陮业 & & \\
\hline \multirow[t]{2}{*}{ 藏荿 } & 各種校㚗と关の意義 & & \\
\hline & 血 清 䏏 炎 & & \\
\hline & 標準体重と心胸比 & & \\
\hline \multirow[t]{2}{*}{ 自 } & 水分摄取量上体重增加 & & \\
\hline & 自己管理ノー上の使用 & & \\
\hline \multirow[t]{2}{*}{$己$} & 薬 物 療 法 & & \\
\hline & シメントの管理と注意近置 & & \\
\hline \multirow[t]{2}{*}{ 管 } & 外来H.DE夜閶H.D & & \\
\hline & 非常時の迹絡方法 & & \\
\hline \multirow[t]{2}{*}{ 理 } & 透析Ptの手虹 & & \\
\hline & 災害时奶策 & & \\
\hline
\end{tabular}

表|指導子ェックリスト
そこで少しでも指導しやすくと検討を重ね，当院なりの 導入期の指導計画を作りましたので述べてみたいと思い ます。东ず指導区分ですが，1.入院より治療方針決定ま で，2.透析開始より退院準備期まで，3.退院準備期，4. 移行期（1 年以内） 5 . 安定期に区切りました。こ机矤 師・看護婦・栄企士が指導区分にあった指導がなされる よう分けたもので，以前活用していた指導チェックリス トの項目を折り込んで指導を進めてゆくといらもので す。尚，導入期の食事指導に関しては，後汪ど発表いた しますのでここでは食事指導以外のことについて発表 いたします。入院より治療方針決定までですが，これは 病棟看護婦により，病気についてンャントについての説 明を行い，病気についての理解と心構光を光うつける

\begin{tabular}{|c|c|c|}
\hline \multirow[b]{2}{*}{ 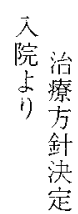 } & 医 & 看＼cjkstart護 \\
\hline & $\begin{array}{c}\text { 病気について } \\
\text { 透析について } \\
\left(\begin{array}{l}\text { 職場・家族 } \\
\text { の方へも }\end{array}\right)\end{array}$ & 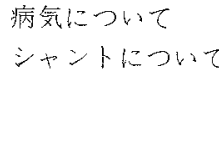 \\
\hline
\end{tabular}

表 2 治療方針決定まで

ようにします。（表2）透析開始より退院準備期までで ですが，a，受持看護婦を決め，受持看護婦が透析開始 前日までに, 透析室の見学とオリエンテーションを行い， 血液逶析の説明を行う。b。指導チェックリストの「腎と 水」人工腎臟」の項目の指導を行う。指尊には当院で作っ ている透析指導の手引学使用し，同一レベルの指導が出 来るようにしています。c、一般状態が安定すれば, 自己 管理ノ一トにより血圧・瓜量・水分摂取・症状など把握 させ記録さ地る。d.内シャントの人には止血のクランプ 学，外ンャントの人にはカニューラクランプを持たせる。 e.食事摂取状態の記入をさせる。を市げ，この時期には 「血液透析を理解させる」ことを目標にいたしました（表 3)。退院準備期ですが，この時期には「自己管理の方法 を患者に把握させる」ことを目標にいたしまして，a。指 導チェックリストの「自己管理」の項目の指導を行う。 b。血圧計・体重計の購入をさせ, 血圧・体重・尿量測定 


\begin{tabular}{|c|c|c|}
\hline & 医 & 護 \\
\hline 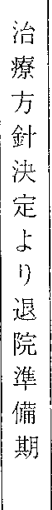 & $\begin{array}{c}\mathrm{b} \text { 透析について } \\
\text { の説明 }\end{array}$ & 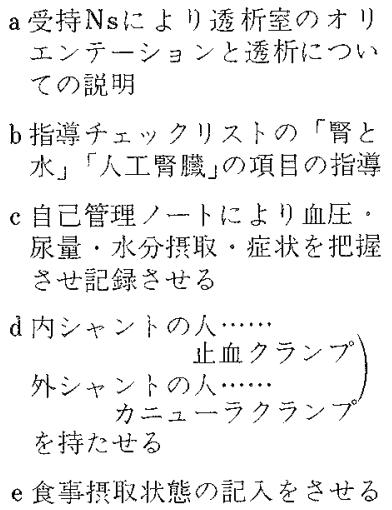 \\
\hline & 〈目 標〉 & 血液透析を理解させる \\
\hline
\end{tabular}

衰 3 退院準備期まで

\begin{tabular}{|c|c|c|}
\hline & 医 & 護 \\
\hline 退 & \multirow[t]{5}{*}{$\begin{array}{l}\text { 外来透析につ } \\
\text { いて }\end{array}$} & $\begin{array}{l}\mathrm{a} \text { 指尊チェックリストの「自己 } \\
\text { 管理」の項目の指導 }\end{array}$ \\
\hline $\begin{array}{l}\text { 院 } \\
\text { 準 }\end{array}$ & & $\begin{array}{l}\mathrm{b} \text { 血压棓·体重計の購入血㽵。 } \\
\text { 体重・尿量测定の叜際を把握 } \\
\text { させる }\end{array}$ \\
\hline 備 & & $\mathrm{c}$ 試験外泊時の家族指導 \\
\hline 期 & & $\begin{array}{l}\mathrm{d} \text { 退院前日までに外来のオリ工 } \\
\text { ンテーションをする }\end{array}$ \\
\hline & & e 人工腎臟患者カードを渡す \\
\hline & 〈目 標〉 & 自已管理の方法を把握させる \\
\hline
\end{tabular}

表 4 退院準 備 期 の実際を患者に把握させる。c。試験外泊の前日には必ら ず，家族指導を行い家庭に扣ける生活指導を行う。d。退 院前日までに外来透析のオリエンテーションを行ら。e。 試験外泊をでに人工腎膹患者カードを渡す。をあげてい ます。(表 4 ) 次に䔟行期として「自己管理の徹低」を目標

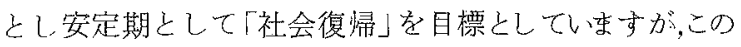
退院準備期までを導入期とし，目標が達成されるように しています。尚最近入院しないで透析に入るといらケー スが多くなってきました。この場合は透析開始後，大体 3 カ月位までの間に指導がゆきとどくよう，受持看護婦 が計画妾立てて行らようにしてい束す。诣導後は患者一 の問診により理解度を把握し，何回もくり返して指導す ることにより効果を得てい屯す。特に透析中は, 肉体的。 精神的不安が有るので，1人の看護婦が受持ら，急变に 備えて近くに居るといら安心感を与えるよう心がけまし た。又，この時期に基礎知識它理解させ，体調の良い患 者の紹介などにより，やる気を起させるように心がけま した。指導時間は透析の安定している午前 10 時〜11 時 頃行ってい里す。以上が当院に扣ける導入期の指導内容 であります。導入期にしっかり理解させた患者は，長期 の透析に执いての自己管理が良い結果となって現われて いることからも，特に導入期の指導は重要であると痛感 いたしました。今後さらにより良いるのへと検討を重ね てゆきたいと考它ています。 


\title{
北里大学病院腎センターでの導入期患者の特徵
}

\author{
五十嵐暳子山崎幸子野地金子矢吹幸子松沢孝子 \\ 武和子米田富子青木智子丸茂文昭大久保充人 \\ 鈴木潤桜井健治 酒井紏小柴健 \\ 北里大学病院腎センター
}

\section{〈要旨〉}

北里大学病院腎センターは，開院以来透析治療を行 なって来ているが，大学病院，もしくはセンタ一医療施 設としての性格から，その透析患者の背景は多岐に及ん でいる。透析患者の延命が図られている一方，各施設か らの長期透析密者が合併症の為に，本腎センターで透析 管理される例が多くなって来ている事，腎移植前後の患 者を常に抱えている事，新たに透析に移行して来る患者 の增加等がこの2〜3 年目立ってきて就，安定して透 析に移行した導入期患者の透析期間が短かくなってきて いる。従って，導入期患者の教育，指導等の諸目的を如 何に達成させるかについては，看護婦の果たす役割は大 きいと思う。これら本腎センターの問題を通して，過去 6 年間の思者突態と経験を振りかえり，大学病院の使命 と賣任，看護婦の使命と役割を課題として考えてゆきた い。

腎不全患者は年々增加の一途をたどり，全国的に透析 の需要以高まる一方である。

北里大学病院腎センターは，昭和 46 年 7 月 28 日より 透析治療を開始してから現在までに約 408 名の患者を受 けてきで年間平均では約 80 名が導入されていることに なり，その間に 81 例に及ぶ腎移植も行なわれて来てい 万.

大学病院としての使命，斗しくはセンタ一医療施設之 しての特徴を持つ本腎センターでの透析症例の内訳けは

1. 保存的治療に引き続く導入期透析

2. 重症期治療を目的とした透析

3.各施設よりの腎移植を目的とした透析

の3つに分けることができる。そしてこれらの透析背景 によって，それぞれの目的を達成させる為には，看護婦 や，技師に課せられた役割と責任も大きいと考光る。

さて過去 6 年間で本腎センターで治療された例を見る

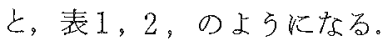

透析総数 408 例中，成人，小児共に，男子にその数が 非常に多いこと，小児透析例が 26 例含まれて括り，その らら 14 例が移植に移行している点に本腎センタ一の特
○透析患者総数……408例

大人 382 例 (男 240, 女 142)

小児 26 例（男 16，女 10 )

叟移植総数……81例

大人 67 例（男 $52 ， 女 15$ )

小愳14例（男 8，女 6)

○他㐌設よりの腎移植目的で透析し移植に移行し た数

大人 25 例 (男 20 , 女 5 )

小児 4 例 (男 2, 女 2 )

表 過去 6 年間北里大学病院腎センターで治 療された症例（昭和47.6〜 52.5現在)

（昭和 $48 \cdot 10 \sim 52 \cdot 5)$

\begin{tabular}{|c|c|c|c|c|c|}
\hline & 氏名 & 性 & 生年月日 & 腎移植月日 & 転㷌 \\
\hline 1 & & $\hat{\delta}$ & $43 \cdot 8 \cdot 22$ & $48 \cdot 10 \cdot 23$ & 良 好 \\
\hline 2 & & $\hat{0}$ & $38 \cdot 1 \cdot 28$ & $48 \cdot 11 \cdot 23$ & $" 1$ \\
\hline 3 & & 우 & $41 \cdot 10 \cdot 23$ & $49 \cdot 2 \cdot 20$ & 透析中 \\
\hline 4 & & $\hat{\delta}$ & $35 \cdot 8 \cdot 21$ & $49 \cdot 3 \cdot 6$ & "I \\
\hline 5 & & 우 & $32 \cdot 6 \cdot 28$ & $49 \cdot 11 \cdot 27$ & 良 斯 \\
\hline 6 & & 우 & $43 \cdot 3 \cdot 22$ & $50 \cdot 2 \cdot 5$ & " \\
\hline 7 & & ㅇ & $34 \cdot 3 \cdot 1$ & $50 \cdot 10 \cdot 22$ & $" \prime$ \\
\hline 8 & & 우 & $34 \cdot 9 \cdot 5$ & $50 \cdot 1 \cdot 21$ & 透析中 \\
\hline 9 & & $\hat{b}$ & $31 \cdot 9 \cdot 20$ & $51 \cdot 3 \cdot 11$ & 死 亡 \\
\hline 10 & & 古 & $30 \cdot 3 \cdot 6$ & $51 \cdot 3 \cdot 11$ & 透种中 \\
\hline 11 & & $\delta$ & $32 \cdot 8 \cdot 21$ & $51 \cdot 3 \cdot 17$ & $" \prime$ \\
\hline 12 & & $\hat{0}$ & $35 \cdot 5 \cdot 9$ & $51 \cdot 4 \cdot 14$ & 良 好 \\
\hline 13 & -- & 우 & $31 \cdot 12 \cdot 26$ & $51 \cdot 7 \cdot 14$ & 死 亡 \\
\hline 14 & & 占 & $38 \cdot 7 \cdot 19$ & $52 \cdot 3 \cdot 16$ & 良 好 \\
\hline
\end{tabular}

(成功率 $50 \%$ )

表2小昌腎移植例 
徴があると思われる。

又大学病院の腎センターとしては，もとより，1 cu 的

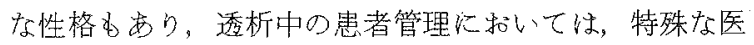
療技術が必要な場合もある。

表 3 は最近 2 ケ月間に括ける重症な透析患者 10 例で

( 52 年 4 月 5 月迄の 2 咸 $)$

\begin{tabular}{|c|c|c|c|c|}
\hline & 年令 & 合 & 転㴆 & 入院日数 \\
\hline $\mathrm{K}$ & 16 & 敗血症＋心外膜资 & 不変 & 77 \\
\hline$s$ & 17 & 敗血症 & $" \prime$ & 42 \\
\hline Y & 6 & $\begin{array}{l}\text { 溶血性尿毒症性症侯群十腹膜资 } \\
\text { 十敗抯症十頭蓋内出血 }\end{array}$ & 死亡 & 47 \\
\hline A & 41 & 心外膜炎十胸膜炎 & 死亡 & 189 \\
\hline I & 33 & $\begin{array}{l}\text { 血滑肝炎十消化性漬痬 } \\
\text { 二次性へモクロマトー・ジス十筋症 }\end{array}$ & 不瓷 & 134 \\
\hline M & 33 & 腎性骨異栄荃症 & 軽快 & 61 \\
\hline$T$ & 38 & 溶血性貧血十ロ内カンジダ症 & " & 59 \\
\hline I & 28 & 督移植后督不全十真性糖尿病 & $"$ & 13 \\
\hline s & 59 & $\begin{array}{l}\text { 䇾性絽尿病十てんかん十静脈循環 } \\
\text { 不全 }\end{array}$ & 不裂 & 148 \\
\hline 0 & 10 & 動脈瘤十創賃感染 & 不亪 & 261 \\
\hline
\end{tabular}

(平均入院日数 1031 日)

(透析Bed 尃有率 55 \%

表 3 重篤な合併症事例

の合併症を見たものであるが，これらの症例のらち，導 入期から症状が改善されず, 重症に陥ったものは 2 例, 他の 8 例は平均透析年数 4,5 年で, 全症例と为透析の 長期化に伴って出現した合併症である。そしてこれらの 症例は全例, 連日透析, 屯しくは予定外透析が行なわれ て特り，透析ベッドの專有率は $55 \%$ にも及んでいる。

各々, 患者は内科病棟, 外科病棟, 小児病棟で入院管 理されている為, 腎センターでの管理も各病棟との連絡 調整を密にすることが必要である。

本腎センターで初めて透析が導入される患者は，他の 病院からの紹介で直ちに透析に移行する例を除けば，外 来での保存的治療期間に, 腎センタ一見学—入院一 ヤシャント造設術—透析治療という段階を踏ものが通 例である。従って，外来での保存療法期沉すで食事療 法を中心にして, 保健婦, 看護婦, 栄養士, ケースワー カー, によってそれぞれの專門分野での教育, 指導を繰 り返している為, 自己管理の理解と実施については, か
なり徹底されていると見ている。

このように，この時期に食事管理や生活管理が徹底さ れている患者では，透析に移行した際，その後の管理が やり易い傾向にある。しかし前述のように大学病院とし ての使命を持つ本腎センターは, 重症期透析患者, 小児 の長期透析患者, 移植前後の透析患者を常に抱えている 為に, 安定して透析に入った導入期患者の透析期間が極 めて短汃事必特徴の1つである。

表 4 のように本年 4 月から 5 月末迄の 2 ケ月間に透析 に移行した患者数は 17 名に及ぶが, その平均透析経過期 間は 13.5 日で, 平均透析回数は僅か 5.3 回でしかない。

52年 4月～5月末迄の導入期患者数 17 名
平坽透析回数
5.3 回
平均透析経過期間
13.5日

\section{表 4}

このうち特に短かい人では 1 回, 長い人でも 19 回の透 析で, 自覚症状の改善, 血圧・体重の安定, 検査成績の 改善を見て, 各々サテライトに移っている.

今後, 安定した患者の導入を大学病院で取り扱らべさ か否か子考兄てゆく必要もあるように思われる。

今迄述べたような観点と立って，現在私達は幾つかの 会合を持って，腎センターを運営して来ている。

1 医師を中心に看護婦, 保健婦, 栄養士, ケースワー カ一, 技師で当日の透析症例の問題点を険討する ケースカンファレンス，

2 看護婦を中心に保健婦, 栄養士, ケースワーカー で連絡会を持ち, 導入期患者の状沉把握や, 指導内 容の打ち合わ就する会合

3 週 1 回の移植チームと腎センター医療チームとの 合同会議である。

\section{まとめ}

腎不全患者は今や抱括医療の対象亡なる代表的疾患で あり，各地域ごとに，その態勢づくりが急がれている。

私達も開院以来，医療チームを組及，常に前向き飞患 者管理に当って来たが，今後とも大学病院腎センターと しての役割を十今発揮出来るよう火努力してゆくつもり である。 


\title{
種々の形の導入期透析看護について
}

\author{
鈴木水映真鍋美紀子満田啓子井上つぎ子村上順子 \\ 田上佐有美 \\ 関東学災病院人工腎室
}

〈要旨〉

当院の慢性血液透析室は外来部門に属し慢性腎不全の 保存療法は内科病棟で行なわれている。ここに 4 例の慢 性血液透析導入前後の看護の実際と経過をのべ今後の透 析看護に役立てたいと思う。

導入期指導項目

1.精神面への援助，家族面接

2。日常生活の指導と管理

\section{3.食飳療法の指導と管理}

4。自覚症状と合併症予防について

5.救急処置と非常時避難訓練

6.その他

\section{症例 I 27 才，女性，}

昭和45年より慢性腎炎にて 外来治療，昭和 51 年 11 月 10 日呼吸困難にて緊急入院， 腹膜透析, 11 月 26 日内シャント手術 12 月 9 日血液透析 開始, 12 月 10 日吐血直与に幽門形成術施行昭和 52 年 1 月7 日心のら液貯溜にて呼吸停止あり，通院加療中より 病識が少なく繁急入院時より今日まで図 1 の如く尿毒症 による種々の合併症，呼吸困難，失禁，褿創，出血症状 頻発，吐血の為幽門形成術施行，肺浮腫，心のう液貯溜 シャント肢拘縮等の合併症を起こしたが兄弟及び婚約者 の暖かい助力を最大の社会復㷌への足がかりとして自暴 自衰になる事がなく、多大の苦痛を乗り切っている。自己

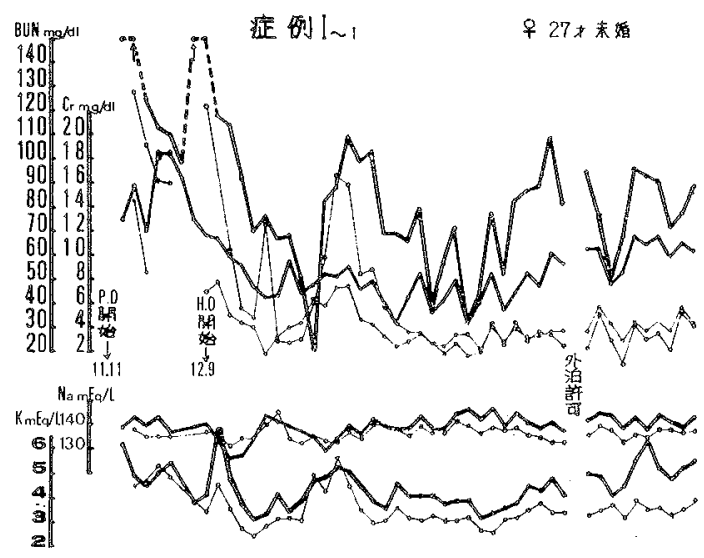

図 I
管理の為の保健指導については各項目で納得できるが試 験外泊させると小柄の割に大食であり水分管理が不充分 で現在は週 3 回血液透析を行いいマトクリットを維持す る事に専念し新家庭設計の為にサテライト透析を目前に している。

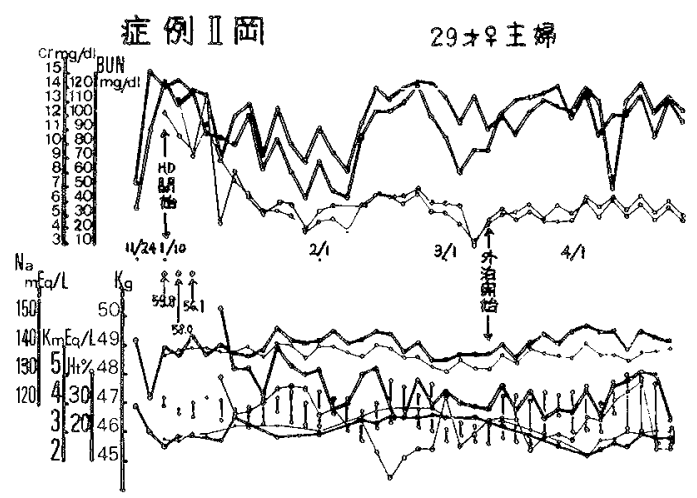

図 2

症例 II (図 2)29才，女性，

昭和 47 年 7 月より急 性腎炎にて加爒, 昭和 49 年貧血にて約 1 年間入院, 血屎, 発熱にて昭和 51 年 11 月 30 日当院入院，12月 24 日内 シャント手術，昭和 52 年 1 月 10 日血液透析開始，通院 中より過度の蛋白質摂取制限があり，貧血症状が強く， 入院後は病棟看護婦八の遠慮があり自覚症状の訴光が遅 れがらで内シャントの発育を促す為に 1 日でも遅い血液 透析導入をといら主治医の意向で保存療法が徹底してい る。正しい病識と今後の保健指導については素晅々のる のの理解を示し的確な質問が多くあり患者の性格を把握 した指導の効果があった。又病室に症例Iが転室して来 たことにより血液透析への不安恐怖が和らざ血液透析に 意欲的となって稀にみるスムーズさで導入されサテライ 卜透析を目前にして，2肾の母として商店の主婦として 又症例Iの良さ相談相手として充実した生活が近い将来 できるものと思われる。

症例III（図 3 ）49才, 男性。

昭和 47 年 6 月萎 縮腎にて他院治療，昭和 51 年 11 月血圧上昇，頭痛，手 指の振せんにて他院入院昭和 51 年 12 月 20 日血液透析 目的にて当院に転入，昭和 52 年 1 月 6 日内シャント手 術, 1 月 20 日血液透析開始, 会社役員としての社会的立場 


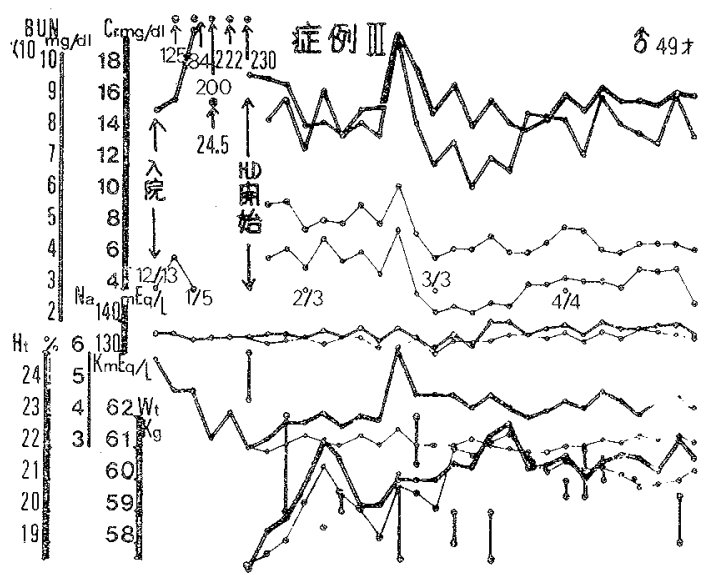

図 3

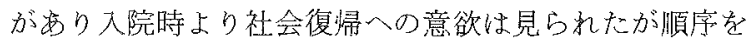
追った保健指導項目の実行についてはインテリといわれ るタイプにありがちな自己本位の言栜が多く見られ医 学雑誌を購読しスタッフのアドバイスを受け入れず慎重 に療虽する熊度に欠け病院の医療体制そのものへの不泗 が強くなっている。入院当初の患者教育を十分行い得な かった点大いに反省するものがある。経済的以安定して いる求以加光尿覃症状が軽度に出現した時比較的速やか に血液透析が開始され死に接した苦しみを知らず家族の 協力理解が全くなく，2，3のサテライト施設を見学し ても患者自身の希望が充足されていない。今後この様な 患者が増觉る事考考完幅の広い看護知識の活用を計りた 次

症例 N(図4)43才，女性，昭和40年頃上り治潦 開始，昭和 51 年 6 月 18 日血液透析目的で当院入院，6 月 30 日内ンャント手術, 10 月 2 日血液透析開始, 当患者 は病歴が長いにるかかわらず継続する治療への病識がな

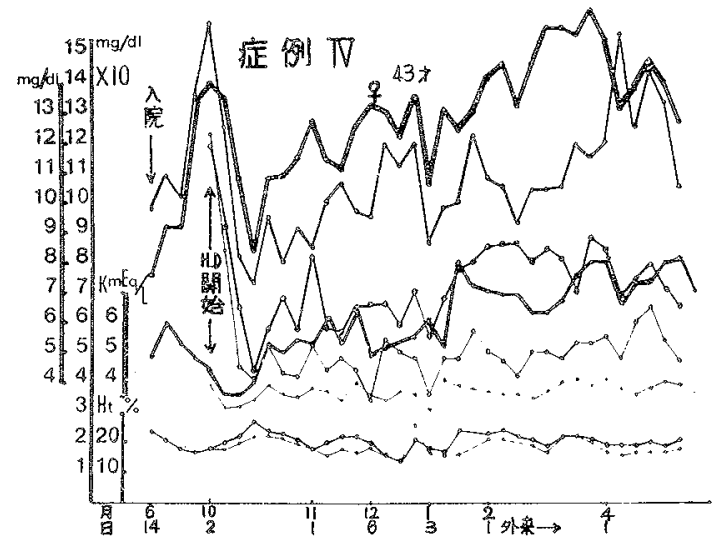

图 4

く，性格が我ままで入院時は病院の方向が悪いからと血 液透析尊入孛拒否したが尿毒症性肺浮腫で緊急血液透析 を開始するや否や血液透析への過信が強くなり水分及び 食事管理，日常生活管理ができ得ない。保健指導する度 に泣いたり，無口になったり，突然腎移植を希望してみ たり，絶食したりして，子供の様な状態となりスライド の如く経過が良くない。施設への依存心が強い為週 3 回 血液透析のらち2回をサテライトで受ける様試みている が高K血症，貧血が改善できず尚充分な血液透析と基砚 的な事項の繰返しの保健指導を要する患者と言之る。

まとめ

以上の様に当透析空に和いての導入期透析仗一広成功 したがやはり入院時から血液透析直前柰での短期間の患 者教育を徹底させる事が重要で自己管理の為の努力と今 後の生活設計は個々の患者の特性を充分に知って行らべ きで㱑り，今後共よりよい社会復帰への看護援助を繶沪 てゆきたいと思ら。 


\title{
透析導入期の患者指導について
}

\author{
横村妙子吉岡典丹治郁子辻口のり子原口真知子 \\ 浅原宏美塩野谷せつ子荒木千鶴 \\ 国立王子病院腎センター
}

\section{〈要旨〉}

透析窒開設以来 6 年間の看謢経験と，患者の経過を通 して検討した結果, 導入期の患者指導の重要性を知った。 そこで，国立王子病院及び関德施設で長期透析实施中の 55名の患者を対象として，指噵方法を検討した。看護側， 患者側の問題点を明らかにした結果, 看護側の問題点は, 一定の方向づけのもとに可及的に解決可能であることが わかった。指導基準と記録用紙を作成し、チームカンファ レンスによる患者把握に基づき，必要事項をもれなく指 導する方法と，䍐者を長期的見地からとらえ。ケースバ イケースの至適な指導を継続するため。主治医のような 形式の受持ち看護婦を定めた。そして，同じ指導基準の もとに，指導の反復を図り，密者の知識の浸透と定着を はかっている。現在この2つの方法により，安定した日 常生活への移行を順調に進められるよう努力中であり, 従来に比較して良い結果が諗められている。

\section{はじめに}

当院の透析室は，本年 2 月を吅開設以来 6 年を経 過したここの間取扱った患者数は100名を超光, 看護面で も種々の変遷を経た。導入期といら語句さ之知らなかっ た初期から，一灾看護方向を認識でさた最近迄の看護を， 患者の経過を通して検討した結果，導入期患者指導の重 要性を再認識した。現な゙，導入期指導を研究し，比較的 良い效果が得られているので第1 報として報告する。

\section{対象}

対象は，昭和 52 年 4 月 30 日現在，国立王子病院及び 関連施設病院で，長期透析を受けている55名で，その内 訳は表1の通りでめる。表 2 は，社会復㷌状態を示した もので（）内梳入 1 年未満の患者数である。

\section{導入期急诸指導の目標と問題点}

私達は，導入期看護の目標を次のように考えている。 (1)透析療法に対吉名患者の理解之協力学促与。(2)導入期 患者の精神的身体的自立への援助。(3)円滑な日常生活へ の適応。孛なわら，導入期に扣ける目標は，完全社会復 州への順調な移行を果たさせることである。以上のよう な看護目標の達成には，言うぬでもなく正しい患者指導

\begin{tabular}{|c|c|c|c|c|c|c|}
\hline & \multicolumn{2}{|c|}{3 回/遇 } & \multicolumn{2}{|c|}{2 回/週 } & 計 & 合計 \\
\hline \multirow{2}{*}{$\begin{array}{c}\text { 国立王子病院 } \\
\text { (疍間) }\end{array}$} & 入院 0 & \multirow{2}{*}{5} & 入院 13 & \multirow{2}{*}{40} & \multirow{2}{*}{45} & \\
\hline & 外来 5 & & 外来 27 & & & 55 \\
\hline $\begin{array}{c}\text { サテイト } \\
\text { (伩閒) }\end{array}$ & 外来 & 10 & & 0 & 10 & \\
\hline
\end{tabular}

表 1 国立王子病院関係透析患者数

(S.52.4.30現在)

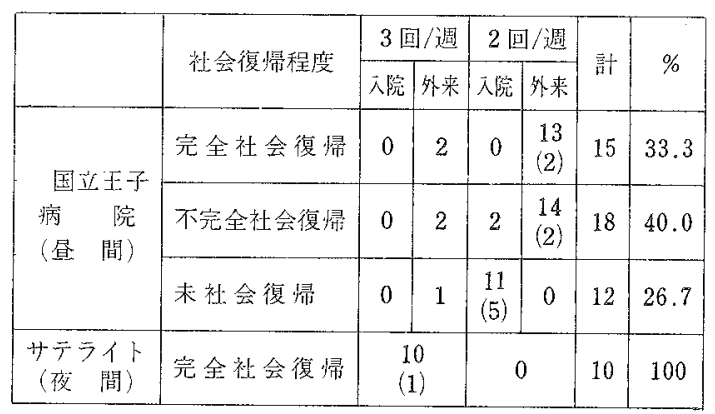

（）内は導入 1 年末満の人数である

表 2 社会復㷌状態

(S.52.4.30 現在)

が基本となるが，実践にあたっては次のような問題点が 考完られる、屯ず, 看護側では，(1)人員棈成上の問題， (2)看護スタッフの閏題、である。透析療法に和いて, 看 護婦の定員は明示されて招らず，当院では週 $2 \sim 3$ 回透 析患者 45 名に対して, 8 名の看護婦であり, 看護助手, 透 析技師が存在していない。このため、これらの職種の業 務玉でが看護婦の業務となり, 本来の看護業務が十分行 えない日も专る、 又, 看護スタッフの能力や経験妇一定 ではなく，透析看護に対する考光方，看護姿勢の違いか ら，患者指導沁执いても問題が生ずることがあった。し

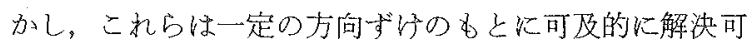
能である。一方，患者側では，身体的問題として透析導 入当初の症状の程度, 年令, 合併症, 知識レベルなどが あり，意欲，関心度，忍耐力，情緒安定度，生甲斐の有 無などの精神面の問題，家庭環境，職場などの社会的面 の問題などがある。これらの患者側の問題は，容易に解 
決できるものではなく，看護体制の調整強化なくして， 対策は立たない。過去 6 年間の看護経験を通して現在の 患者をみる時。導入期の患者指導が㧍るそかにされた ケースでは，自己管理できず長年にわたり苦しむ患者が 多いことが認められる。つまり，表面的なきれいごとに 終らない本質的に有効な指導方法を確立し，それぞれの 患者に最適のペースを早く体得させることが不可欠と考 完られる。

\section{導入期患者指導の方法}

当センターでは，チームナーシング制をとっているの で，毎日の透析患者を $2 \sim 4$ 名割当て，その受持ち患者 を中心として看護羓務を行ない，それと同時に，患者を 長期的見地からとら光，ケースバイケースの至適で綿密 な指導を継続できるよう主治医のような形式の受持ら看 護婦を定めた。これは，チームカンファレンスによる患 者把握と, 看護スタッフ間の意見や指導方向の一致を基 本とし，日常生活上の必要事項をすべて綱羅するため導 入期患者指導基準を定め，指導記録によ々それを継続的
にするもので，患者の知識の浸透と定着を図っている。 現在，この 2 つの指導方法を併用することにより導入期 から安定期に移行した患者は，わずかであるが，安定し た日常生活への移行へと覑調に進められるよう努力中で あり，目下のところ従来比較して良い結果が認められ ている。

おわりに

健康上最大のハンディを負い，な扣日常生活面での基 本的欲求が充たされない誘惑の多い状況の中で，持続的 な苦痛を耐えな悦ればならない患者達の状態を知ること 加ら，導入期看護は始交る。そして，生涯透析寮法安続 けていく患者にとって導入期に括ける指導が基本とな る。我々は、どのような状態で導入された患者に対して もな拉,っースバイケースの綿密な指導ができるよう努 力し，その看護を通して患者に人の一生を生きる上での 自信を持たせるよう、今後看護面での多くの命題を追求 して行かなければならない。 


\title{
透析導入期の患者指導一反省と今後の指針
}

\author{
林百合子安井久江鳥越幸子根木香中村紀美子 \\ 原敬子那須美代子沖元伊津子山田和代植田千春 \\ 矢野道代井上喬之 \\ 川崎医科大学附属川崎病院人工腎臟室
}

\section{〈要旨〉}

安定期に入うた透析者 27 名を対象に私達の行なってき た導入期における患者指導が、その後どの様に理解され受け とめられてきたかを知るためにアンケート調查を行なっ た。その結果，1。導入時における透析知識については， 約半数のものが教育不足，2. 食事指導については，大半 が理解していたが実際に日常生活で活用していると答え たものは $44 \%$ に過ぎなかった。3。日常生活と自己管理に ついては、特別な例を除いて殆んどが良く理解していた。 4。医療社会事業については，身障者手帳や年金制度につ いて充分活用されていなかった。句家族指導については, 家庭訪問を行なったがその結果，社会復帰や食事指導に ついて家族の理解度は $50 \%$ と低く，家族への指導不足を 知らされた。導入期における患者及び家族指導が，ただ 単にスムースな導入を計るのみならず移行期，安定期を 経て透析本来の目的である完全社会復帰を得させるため にも重要であることを痛感した。

\section{はじめに}

現在，私達の透析室では殆んどの透析者がすでに安定 期にあり，一応，尊入期に括汁る患者指導は5まく行な い得たと思われる。しかし個々の例についてよく又ると， 完全社会復帰を遂げ生活意欲も旺盛な人達から，いまた に入院透析を余儀なくされ，また精神的にる立ら上れな い人達までさまざあである。これにはそれでれ医学的， 社会的な理由にもよることだが，一方，私達の導入期に 扣ける指導方法によっては，もっと巧く指導し得たので はないかと反省される面も少なくはない。そこで私達が これまでに行なってきた患者指導が果してどのように患 者に理解され，また受壮とめられてきたかを知る目的で アンケートルよる調査を行なってみた。

\section{対象と方法}

対象：昭和 47 年 2 月以降, 当人工腎臓室で扱った透析 者数はのべ 51 人で，現在透析中のものは 27 人である。 この5ち入院透析 10 人，外来透析 12 人，外来夜間透析 5 人で,完全社会復帰者は外来透析者中 13 人となってい
る。アンケート調查はこれら現在透析中の 27 人を対象と した。

方法：アンケート調查は，1。導入時に扣沪る透析知 識について，2．食事・栄養指導について，3．日常生 活と自己管理について，4，医寮社会事業について，5. 家庭指導についてとし，それぞれの項目につき“はい" "いいえ"の解答を面談ないしは筆談によって行なった。 また家族指導については，27家族に家庭訪問を行なって 調査した。

結果

1. 導入時に扣计る透析知識について（図 1)

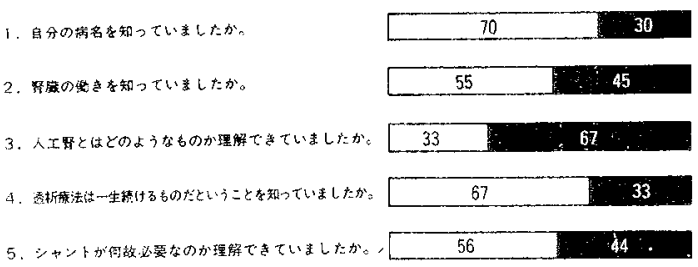

図 1 遵入時における透析知識について

殆んどの者が透析開始前のオリエンテーションによっ て大方の知識を得ていたが，人工腎藏とか透析療法の実 際については知識不足で，特に透析療法を一生続汁るる のであることを知らないと答えたものが $33 \%$ もいた。

2. 食事・栄養指導について（図 2)

入院患者のらち病院の透析食が嗜好上あまり好ましく ないと答光た者が $37 \%$ あ，補食しているものが $74 \%$ む いた。当院で快月 1 回の食事指導会と希望者だけの個人 指導を週 2 回設けているが，食事指導会への継続出㢈率は わずか $26 \%$ と低謂であった。指導会で理解できないと答 光たものが $41 \%$ むいたが，塩分，水分，蛋白，カ口リ一なと 指導の要点については，外来透析者は注理解していた。

3. 日常生活と自己管理について（図 3）

殆んどのものが検査成績やンャント，体重管理につい ては注理解していた。社会復帰者では職場や家族で理解 

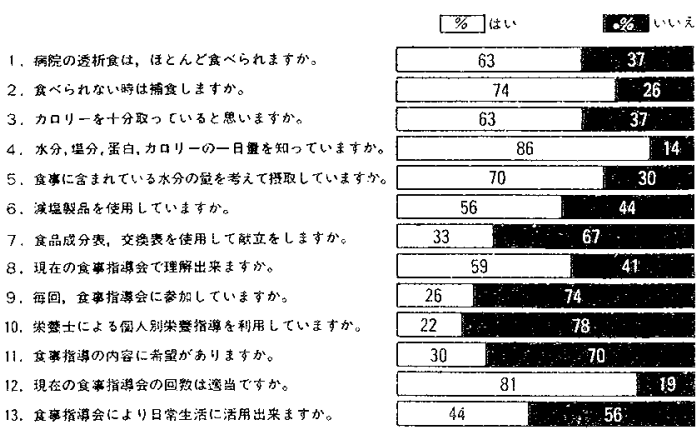

図 2 栄養指導について
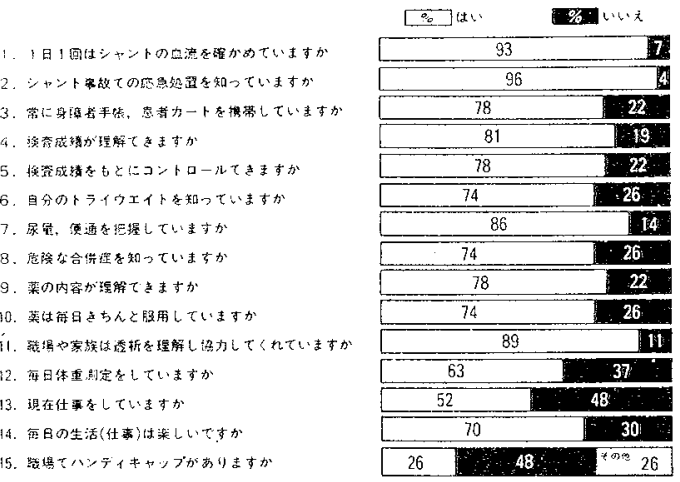

図 3 日常生活と自己管理について

協力を得ているとしながらす，日常生活や職場でのハン ディキャップを訴えるるのが半数にみられた。

4. 医療社会事業について

更生医療や育成医療など公費負担制度や障害医療助成 制度，障害年金，福祉年金などの知識について8 項目に わたり調ベた。更生医療，育成医療制度については泉く 知られていたが，身障者手帳の活用法とか年金制度の受 叮方については知らないものが多かった。

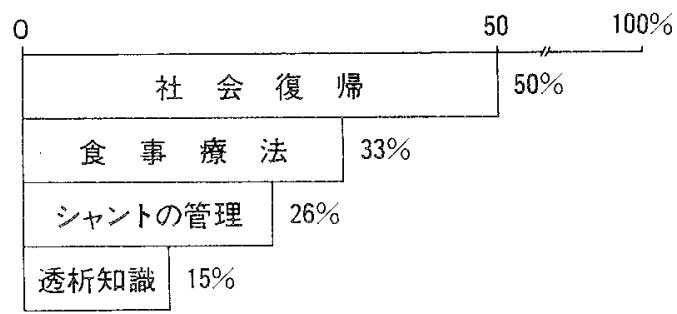

図 4 家族の理解度

\section{5. 家族指導について（図 4)}

家庭訪問を行なって調査した結果，入院透析者の家族 内では多種多様の不安々緊張がみられたはか，特に社会 復帰について㞲不安が先立ら $50 \%$ 程度の理解しか示さ れなかった。 また外来透析者の家族のうらでも食事管理 に理解を示した家推は $33 \%$ 火過ぎず指導不足が示され to

\section{考察}

以上，今回のアンケート調査の結果から，総じて感ぜ られたことは透析者自身への指導はもとより，特に家族 への指導不足といらことであった。そこで私達は導入期 に扣ける患者指導の今後の指針として，1。導入期に扣け る家族指尊は代表者だけでなく複数とする。2.食事指導 会に㥙患者のみならず，必ず家族を参加さ也る。3.生活 指導会を作って患者・家族との連携を保ら社会復帰に導 く，などの項目を目標に指道に充実を計りたいと考えて いる。

\section{文献}

1. 小出桂三。声岡 典著 : 「透析療法と看護」一慢性疾患患 者としての人工透析患者に対する看護一p.79, メヂカル フレンド社, 昭 50 .

2. 柴垣昌功編集：「透析患者の看護」一透析目標とその要 点一 p.51, 医学書院, 昭 50 .

3. 二木シジェ編集：「透析に扣惊るチーム医療」一第 2 章, 医学社会事業部の実際—p.171 HATO 書房 : 1975. 


\title{
導入期透析の目的と透析ヶアーに対する提言
}

\author{
永田景子関口志津子前田憲志*岸常規* \\ 名古屋大学分院透析室 同内科*
}

\section{〈要旨〉}

導入期の精神的不安，緊張感をとり除いて自己管理法 の概念を認識させ，自己管理能力を開発させるべく援助 する專は，長期透析医療へスムーズに䔟行させる第1の ポイントであり，早期社会復帰の鍵でもある。

慢性腎疾患保存期をふくめた導入期教育は，非常に重 要な意味をもち、この時期の指導にあやまりがあると、 その後も大きな問題を残し予後にも大きく影響する。そ の為個々の虫者の問題点を把握し，きか細く対姦する事 が大切であり，その姿勢は患者の個性を尊重して，暖か く，撖しく，科学的な目でもつて援助なされねばならな いと㾑感する。

事例 2 題から具体的な援助法について述へた。

S 43 年より123名の透析患者を導入したので,その経 験加ら導入期透析の目的亡援助方法について考光た。

1 長期透析医療へのスムーズな移行をはかる。

a)自己管理能力を開発させ早期に社会復帰させ る為の指導を行う。

b)家庭透析者とほぼ同じ指導を行い将来の透析 形態を自由に選択导せる。

（夜間、家庭、その他）

c)合併症の予防及び重症患者の改善をはかる。

2 透析条件を整之無症状透析を行门。

表 1 導入期透析の昌的 (当院)

導入期の目的は（表 1)，安定した長期透析医療へと。 スムーズに移行させる事にあり，導入期に於いて自己管 理法の概念を認識さ边る事が重要でする。自己管理能力 は本来どの患者です持ら合わ书て和り，能力を開発させ， 早期に社会復帰させるか否か虻，当期の指導力によると ころが扣括きく，将来ともべットから離れられない長期 患者を育てない為の努力が要求される。

当院では，家庭透析者と㴗活同じ指導を，同垒で通院 患者にも施行して扣り，このようにいつでも家庭透析を 行点る程度の知識の習得之，心構之老確立する事は，将 来患者自身が透析形態を自由に選択するのに有利です り，自己管理の向上にも役立っている。しかし導入期患
者の精神状態は極めて不安定である為，その点を配慮し つつ自己管理指導をす寸ぬる必要がある。

1 初回より無症状透析走行う。 a)短時間連日透析 $(3 \mathrm{~h}-3$ 日間 $)$

$$
0.6 \sim 0.9 \mathrm{~m}^{2} \text { の膜面積 }
$$$$
\text { ( RP減少 } ミ 二 \text { H.F.K) }
$$

b)処方透析 ( $\mathrm{Na}$ 濃度 $\mathrm{kCl} \mathrm{etc)}$

c) E cumにて除水。

2 すぐれた技術を提供する。 初回の穿刺结失敗马せない。

3 人工腎の現洗を正しく把握させ明るい展望である 事在認識させる(家族共に)

4 庇護的 $\rightarrow$ 活動的日常生活への切り加之を無理なく 行わせ自信を持たせる。(食事、運動、シャント、 精神面への適切な援助)

表 2 不安感をなくすための配慮点

当院では透析条件を表 2 の如く整え施行した場合は， 15 人の導入者のら号 14 人迄全く症状がなく，不安感を 軽減させている。初回の内シャントの穿刺は必ず失敗さ せない等，特に導入期患者には卓越した手技で接する事 が著しく不安感を減少さ也る。な和現在社会復帰してい 当患者の多くが，導入期の不安飞“数年の命だと考元 ていた事に市ったと述べている。この事からる人工腎の 状沉を正しく把握させ明るい展望である事を患者には勿 論，家族にも十分認識させる事が必須である。その他先 輩である患者との対話，尊入前の透析スタッフによる病 室訪問指尊，患者の透析室見学等も，早期になされる事 が望ましく，この様な経過を経た患者に於ては，たいし た抵抗もなく，導入期透析を受け早期に社会復帰する場 合が多い。

次に慢性腎疾患保存期与含めた導入期指尊の必要性を 痛感した症例から援助の実際をのベる。48才，

(表 3 )。入院後，人工腎の必要性を知らされ，抑らつ， 無力状態となり透析を拒否して3 週間拒食を続けた例で ある。拒食の原因は，通院時に適切な指導がなされなく， $3 \sim 4$ 年の命であると信じ込んでいた，加光て家族の人 工霄に対する知識が全く欠如して扣り患者の不安感，焦 燥感を理解しえず，精神異常者扱いをしていた等にあっ 
症例 1

透析を拒否して拒食を続けた例 48 才 男子

S 33年督炎と診断走れ通院加療

52 年 2 月導入の為入院

$$
\text { クレアチニン } \quad 9.7 \mathrm{mg} / \mathrm{dl} \quad \mathrm{K} 3.4 \mathrm{Eq} / \mathrm{l}
$$

Bun $175 \mathrm{mg} / \mathrm{dl}$ B P $120 \sim 80$

入院後人工督の必要性を知らされ抑うつ状態上

なり約 3 W拒食無力状態となった。

\section{3 月 12 日導入}

遒入後は全く順調に経過され自己管理の理解も

良好にて4月9日得にライト転院社会復慢马 れた。

本事例は慢性腎疾患保存期もふくめた導入期の指尊 不足を反省させられた例である。

\section{表 3}

た為，家族，親友を交党受持医師，看護婦で説明を重水 た。導入期前後は一時的に精神的なショック状態になるこ とはあっても必ず回復する事を話し，特に配偶者には暖 かい，いたわりの心で接する様指導した。導入後は自己 管理の理解力も良好で 4 週間にてサテライトへ転院, 社 会復㷌された。

症例 2（表 4) はグッドパスチャ一症候群の 15 才の女 子で生命が危ぶをれる状態でK腎センター上り転院. 困 難ではあったが自己管理力及び家庭透析に移行出来る知 識と技術を母親と習得した例である。本例に於ける問題 点々対策は(1)導入初期の水管理が不良で貧血が強度であ り，食事摄取量が不足で偏食であった。この為 ECUMを 透析每に行い体重を $30 \mathrm{~kg} \rightarrow 25 \mathrm{~kg}$ に減量させた。 bed サ イドでの栄養指導に加えてアミノ酸の点滴を施行した。

\section{症例 2}

重篤な合併症を持ち自己管理の習得が困難だった思 春期女子の例

15 才

S 48 年 2 月感冒罹患後顔面浮腫 $(+)$ 亲フローゼと診 断寺九近医入院。

S 48年11月当院転院雨急性腎炎と診断采れ50年 5 月 クレアチニン等 $\uparrow$

K、腎センターにて透析開始守るき発熱、血痰、呼 吸困難等市り再び当院入院。グッドパスチャー症候 群と診断される。

入院時 顔面蒼白、強度筫血 $(+)$ 血痰 $(H+)$ 咳嗽 $(+t)$ 視力減退 呼吸困難 $(+)$ BP $170 \sim 130$ Ht $12.9 \%$ RBC $128 \times 10^{4}$ 。

表 4

(2)母親への依存度が強く対人関係に拐いて閉鎖的であっ た為母親としばらく離断させ食事等は，一人でさせ，ス タッフとの対話を多くして無口な患者に出来るだけ発語 させる様試みた。透析後の散歩, 湤髪等も行いスタッフ との親しさも増し受容関係をもつに至ったので徐々に悠 しく，自己管理の指導を開始した。主治医に対しても自 分から症状を話し母親の手技のま違いを指導する迄にな り，水管理も良好となった。ステロイドも溸減（1 Tah 3 投 4 休) され RBC2 $24 \times 10^{4} \mathrm{Ht} 12 \%$ 加 $24 \%$ に上昇, 外泊を楽しみにする迄になった。本症例は，合併症を持 つ重症患者に於いて子問題点学把握し，きめ細かく対処 する事によって改善せしめ, 家庭透析にいつでも移行出 来る手技等習得出来た例である。 


\section{討論}

前田 第 1 会場と第 2 会場というらうに分什委して， その第 1 を上田会長先生が物取りいたたいたということ は，とりもな执さずいまの透析そのものに和いて，ナー スの部門の，特に導入期透析というものが非常に大事な 面であって，恐らく透析がうまく成功するかしないかと いうことは，このナース部門に执いての導入期指導が， あるいは患者指導がうまくいくかいかないかといらこと に，かかっているのではないかと言っても過言でない。 そらいら御配慮を上田会長がして，第 1 会場として皆さ ん方のために、メーンのテーマをここに持ってこられた と思らわけです。

この透析について，いろんな討論が尔るわけですけれ ぞも，今年皆さん方の，特に国際的なナースの集㐬りが 有りょした。それで，日本のナ一スと言らか，看護の面 からしますと，むしろ後進国と言われる，あるいは発展 途上国之言われる所に为劣っている面が，随分有る上う に感じました。例完ば、ナースの大学院がまだ日本には 存在してないことも，その1つではないかと思い束す。

この研究会の会誌と言い类すか，プロシーディングを 御覽になって子，扮分かりになる方为いらっしゃるか子 しれませんが; やはり発表のレベルを上げるためには， 学問的な書き方，めるいは学問的な把握の仕方，発表の 仕方をできるだけさちんとすることる，非常に大事なこ とでありますので，そらいら修練も兼初て，皆さん万に 是非立派な御発表を打願いしたいと考光て扣るわけであ り亦。

\section{1。に対する討論}

前田 受持ら看護婦制といらことと，ルーム・リー ダー制を持とりになっているわけですけれども，今の ナースの場合には汪とんど 3 交代ということが，特殊な 部門は別としまして，行われているものですから，受持 らといら制度はそう多くはないだろらと思いますが，昔 私たちが医者になりたてのころは，全部受持ら制が多 かったわけです。そのいらいろな欠点，長所，また恐ら く同じよらなことが出てくるかもしれま世んが，現実に 私はどらしてもこのドクターがいやだ，あるいはこの看 護婦さんがいやだと言われたとさには，ぞういら反応の 仕方をするんですか.

䅱崎 やはり，患者とウマが合わないと言うんですか， そらいう場合子時々出てくるんですけれども，そういう とき火はそういう問題点は，朝のミーティングのときに 出てくるわけなんです。そうしたら，婦長なりほかのメ ンバーなりがそれを補佐しまして，あの人がいやだから
じやあすぐ受持らを変えましょうと言うんではなくて， しばらく経過を見るよらにして特ります。やはり，誠意 を持って接していたら，搞互いになた通じる物子有りま すし，特に私の所でそれに関して大きな問題は出てきて 和りません。

前田いったん受持ちになりますと，もら何年も同じ 方が，転勤される場合は別ですけれどる，ずっと見て括 られるわ惊ですか。そのつもりなんですか。

豊崎 はい。大体，1度受持ったら続いて执りますけ れども，新しい看護婦が入りまして，その人が新しく患 者を受特つ場合，問題点の多い導入期の患者をすく受持 つのは，いろいろ問題が出てくる場合が有るので，そう いらとさには慢性期に入っている患者を先に持つ。だか ら,引き続さ新しい看護婦が，古い看護婦が持っていた 患者学次に受持つ。それで，大体指導の内容が慣れてか ら，また新しい導入期の患者を受持つとい.ら形をとって いますので，時及受持ら患者を変光ることは有ります。

前田分かりました。どなたか，御発言か御追加ござ いますか、忹かにも，あるいはこの後でも受持ち制をとっ て频られる所が有り李が，今のルームリーダーという 点では，昔は各ドクターの場合には，いわゆる上医と言 いますか，上の方のドクターがいまして，それがその部 屋の主任なんて名前が有ったんです。そういらことで, 室長的な指導をして和ったんですが，ナースの場合は病 棟なり，あるい恪笚位ではもららょっと大きなり一 ダーは居るわけです。

\section{2。に対する討論}

前田らょっと時間がオーバーしてい屯すが，なかな か堂々として，ありがとうございました。らょっと伺い なすけれどす，緊急に入ってきた方の指導をする睱が無 いときは，後からどらいうふらにやりますか。

窪田はい，全部シャント作って全部やりまして，後 から颃い执いといらことで，全くこのオリェンテーショ ンは崩れてしまい亦すけれども……

前田 その場合の成績と言いますか，初めにらゃんと ケアを指導されたとさは，非常に軌道倸ってらまくい くと思うんですが，その余裕の無かったときの，後でこ の表のような形に追い付くためには，相当苦労されます か。そのときのやり万といらのは……

窪田をうですね，余り李だ経験が無いんですけ计れど も，やはり本人の意識の持ち方と言いますか，とういう 点で大分違ってくると思い子す。覚悟の仕方と言っては いけないんですけれども，説明していくらちに本人もだ 几たん自分で意識してきますね。それが突然ですと，意 識をするのに時間が掛かることが多いと思い宥す。

前田そらいら人の方が，後で非常にやりにくいとい 
うことは有りますか。それは特に有りま世んか。

湦田。をだ余り感じていません。

杉崎 意識障害があって導入する場合，大体 2 週間か ら 3 週間で意識障害が改善した段階からが，大体導入の II 期といら感じでケアして拈ります。

前田 先生，その場合の，指導していきまして，そら いう苦しみを味わった人と割合にスムーズに導入できた 人で，後の指導に何か差がございますか。

杉崎やはり，苦しんできた人の方が後の管理はいい ようです，感じだけですけれどす。別に，統計といった ことが有りませんので分かりませんけれどむ。

前田潘かに御質問ございますか。どうぞ看護婦さん の方々，いろんな同じような問題を抱交られているわけ ですから，まだそのムードに，気分に乗らないのかるし れま好んが，御遠慮なく御発言なさってください。

\section{3.に対する討論}

前田私からまた伺わなきゃならないかもしれをせん が, 勤務の場合に病室訪問と今拈っしゃられたんですが， 病室のスタッフと透析室のスタッフとの間の交流々言い ますか，人事的な面の交流はございますか。

坪野 各内科病棟へ人工腎朦室からパンフレットを渡 してありまして，このような理由で透析に入る患者に， 導入期指導を行いたいという説明が前もって行って括り ます。そして，導入期指導を行う場合には，昰ずその病 棟へ連絡を取りまして，その病棟の看護婦と患者につい て，申し送りを含めた話し合いを持ちまして，それから 病室に行くようにして拈ります。

前由 例之ば，内科病棟々人工透析室との間のナース の交流之言い委すか，3カ月たったら透析室に勤務が配 置替光になるようなことはあるんですか，同じ内科なら 内科同士の。そういらことは無いんですね。病棟の勤務 から透析室の勤務へ，そらいら配置替之というのは，何 か規則的に行われることは有りますか. 全く別個の病棟

として…..

坪野い充，内科病棟加ら来て和方すす。

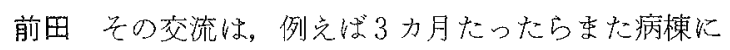
戻るとか，あいい唀析室に移るとかというような，回 転と言い李すか……

坪野はい，回転になって扔り东す。

前田 それは，必ず回転するようになってい亦すか。 内科だけですか。

坪野 内科病棟の中に透析室が含まれて扣りますけれ ども，慈恵全体の内科病棟ではないわ蛙です。

前田专る特定の病棟から交代寸るわ沙ですね。

坪野はい，そらです。

前田分かりました。

\section{4.に対する討論}

前田今の鳥取県中央病院の方の発言も，やはり受持 ちナースといらことについてなさったんですが，甲南病 院の豊崎さんいかがですか。同じような御発表なんです が，何か御意見どうぞ。

豊崎 外来患者を導入する場合飞，受持ち看護婦制急 とっていらしたら，指導なんかに関して時間的な物と言 うんですか，時間外の指導が多くなるのではないかと思 らんですけれども，いかがでしょらか。

前田 最近になり李してから，外来透析の人が増えて きまして，1遇間に1回ぐらいの割合で大抵透析にい らっしゃいますので，そのときを利用して大体やってい ますし，受持ち看護婦が必要であれば，また時間を後で 設けて来てもらうとか，食事指導なんかのとさに，一緒 に時間を設けてやっています。

林本 自分の所で導入した患者だけでなくて，添かの 施設からも透析の患者が送られてくると思らんですけれ どす，すでに透析を受けてこられた患者を受け入れられ た場合，受持ち看護婦制をとっていらっしゃるそうです が，その辺でのトラブルなんかは無いんでしょうか。

前田 紹介状なんかに，医学的なことの紹介は有りま すけれども，ナースに関しての導入期をどうしていると か，そういらことに関しては有りませんので，一応受持 らがどのくらい指導がなされているかと聞さまして，付 け加完ていく場合はとれに付け加光たりして，患者さん によく聞いて，それで当院なりの指導方法で続けてや。 ていっています。

林本 透析室に勤務していらっしゃいます看護婦さん の経験年数なり，1人 1 人の知識炕よて，患者さんに 与交る物も違うと思うんですけれども，その辺で大体何 力月ぐらい透析室に勤務されてから，受持ちをなさるん でしょうか。

前田 4 カ月ぐらいしをしてから，大体チームリー ダーみたいなのを付けるよらにしていをして，受持ちは 1 カ月したら慢性期の人を受持つようにしていますけれ ども，アドバイスをしながら1人でなくて，そういう場 合はやってい李す。

林本どうるありがとうございました。

北崎(望星クリニック) 先ほどの質問者の方に関係あ る質問でございるす。受持ち制が良いということは，非 常に言われて拈りますけれども，やはり経験による差が 指導内容に非常に影響してくるんじゃないかと思い穼 す。それをガー一する意味で, 横須賀共済が非常にュニー クな体制をとっていると聞いて挌りますけれども，もし できましたら，宇田さんにちょっととの辺簡単に説明し ていただきたいと思います。いかがでしょう。 
前田分かり委した。宇田さんいらっしゃいますか。 どらぞ物願いします。

宇田(横須賀共済病院) 受持ら制だけでは不十分だと いうことで，患者管理と教育研修，物品管理などのいる んな面での管理という，受持ち制に加えてそういう3つ のプロジェクトチームを作りまして，それで受持ら制か ら出てくる久点をカバーしている面があります。それで よろしいでしょうか。受持ら制に加えて，プロジェクト チームと言いまして，らをく表現でさないんですけれど 当，そういう立体的な動き方学してい委す。

前田はい，分かりました。いかがですか，今の就答 光で……受持ち制の経験不足を，プロジェクトチーム といら，全体1つのあるチームを作って，カバ一して和 られるといらことです。

甲南病院の場合には，ルームリーダーというものがあ るんですが，そらいら点す1つ以経験の不足をカバーさ れているんですか。豊崎さん，いかがですか。受持らナー スの経験の足りないところは，ルームリーダーがカバー することになりますか。

豊崎 当院では，受持らを持つのは最低半年以上透析 室勤務を経験した人が，受持つようにして拉ります。そ れでも問題点が多いよらな場合には，朝のカンファレン スのときにそらいら問題提起がされるわけです。そこで， ルームリーダーなり，患者のいる部屋のほかのメンバー が補佐したり，最終的には婦長子責任を持って指導して 和り亦京。

前田めりがとらござい承した。これは，後で明日の 総会のときに小高先生から执話があるわけですけれど も，透析の患者さんが増之て，また透析をする施設が急 に増えているわけです。透析専門のナースが足りなく なっているところからあるいは経験年数の少ない方も， 透析室に勤務しなければならないといら事態は，これか ら非常に多いことだと思います。をといら意味で，透析 つ経験だけでなくて臨床経験と一緒に併せて，いろいる 指導されるべきだろらと思い屯すが，その辺についてま た後からいるいる問題があると思います。

\section{ら。に対する討議}

前田大学病院で寸から，安定期の透析をやるかどう かといらことは，確かに問題ではありますが，1つ招伺 いしたいんですけれども，これは透析の患者さんをサテ ライトに拙しになりますね。そのとさに，医師はいろ いろ今までのデータなり経過なりを書いて，患者さんに 添えて持たせるわけですけれど尚，ナースの側として何 かそれに相当する物を付けて，和出しになることはあり 李すか。

山崎 はい,ございます。
前田 サテライトのナースの方にあててですか。

山崎とらです。ナ一スと技師，栄養師，ケースワー カ一，すべての方が連絡票を作って执りますので，それ に記入しまして，患者の状況やら内服薬，食事指尊でさ ているか，できていないかとか，てらいらことる全部書

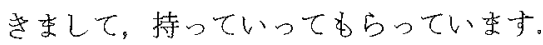

前田それは，北里大学のサテライトだけでなくて， よその病院に和出しになる場合はどうでしょらか。

山崎 すべて患者が移動するときは，それを付けて渡 して却ります。

前田ただいまのは，非常にいいナースの側からの仕 事の内容ではないかと思いますが，いかがですか、任か のどなたか御意見ございますか。とかく，医者は割合に 畫くのが非常に不精なのが多くて，なるべく経過を詳し く分加りやすく書いて, 送らなければいけない九ですが， それが往々にして不汾な点が有るか子しれは世んが， 私たらの所へ送られてくるので，問題の無いヶースが多 い点が有るかもしれませんけれぞも，余りナースの側か らそういうものを付けて，医者の紹介状なり，女るいは 経過録と一緒に送ってくださる例は，割に少ないもので すから，大変参考になるだろらと思います。

\section{7。に対する討論}

前田 国立病院は，非常に人員と言いますか，定員の 制約があて，なかなか苦学するところだと思います。 らょっと㧩いしますが，一番終わりでしたか、スライ ドに体調の把握と言いましたか，そのところで血王とか 尿とか身長比とかめったんですが，呴血の状況なんてい， らのはああいら項目に入るんですか。

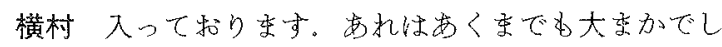
て，指尊基準の内容の方があれがもっと具体的になって きているわ惊なんです。

前田実際にはですね。

\section{8.に対する討論}

前田今の発表の中で，食事指尊に出てくる率が非常 に少ないといら理由は，何かございますか。

林 そのことで，らちでもすごく問題になっているん ですけれども，内容がいつも同じだとか，聞いても分か らないとか，何かとらいら理由で出摩率が低いんです。

前田つをり，栄昱士さんの括話が難しいということ ですか。

林齐，方です。

前田 その場合に，食事指導のときにナースも一緒に 出て和战委才加。

林はい，職場の事情が許す限り，できるだけ出席は してい类与。

前田ナースの側加ら牧聞きになって，栄養士さんの 
指導は確かに難しいんでしょらか。それとも，患者さん の理解度が低いことの方に原因があるんでしょらか。

林 そうですね，私たちが聞くとそんなに難しいとい ら感じではないんですけれどる，專門的な言葉を使って 指導なんかしているみたいなので，患者さんの知識のレ ベルk合わせて，もっと分かりやすく，実際に家庭で活 用できるような話し方と言らか，ただ教科書的にそれを 説明すると言うんじゃなくて…...

前田々の場合に，例完ばナースの側から栄養士の指 導について補足的と言いますか……これは，先ほど医 者として非常に反省させられる点があったんですが，医 者の説明よりも同じ仲間の人の話の方が，よく分かった というアンケートが,どこかの演題でござい先した。我々 の説明が，往々にして難しい言葉を使って，肪って患 者さんの理解度を弱めると言いますか，場合炕よっては ある $1 つ の$ 目的を持って, 殊更難しい言葉を使わなきゃ ならないのも有るんですけれども，そらでなくて，ナー スの側から医者なり栄養士なりの説明の不十分なところ を補うことも，1つのやり方では书万うかと思います。

もら1つ,これは私たちの病院で性格がちよっと違う ので，御参考になるかぞうか分かりませ九けれどる，内 科の患者さんでない，一般の整形外科の患者さんに，そ らいら栄養に関することを聞いてみるすと，汪とんど 10\%ぐらいの人しか理解できてないんです。つまり，糖 質であるとか脂質であるとかたん白質であるとか，そう いうものについての理解が汪とんど無いと言っていいく らい, 今の日本の患者さんのレベル性非常に差が有って, よく知っている人は，沢山いるいるな栄養のことを分 かって扬委すけれども，知らない人はをるっきり分か らないといらことが，1つあるだろらと思い本す。

も51つは，我々自身が何か知っていて子，ぞうせ理 屈は分かっているんだ。ただ食うな，食うなと言うだけ で，危の間に何の土夫も無いではないかといらことが， 恐らくあるだろうと思うんです。ですから，そらいら工 夫を，各人に合ったような，何かこれだったら実行でき るというものを，我々が探さなければならないだろう。

これは，昔，徳川家光だと思いましたけれども，侍医 と言うんですか，御殿医之言うんですか，主治医が非常 にいい医者だったんですが，だれかがそ称んでざん訴し たんで寸。あの医者は，自分の薬箱を米の重さか何かに 例之て卑しい。つ交り，昔は武士は刀とか何か性非常に 大事な物だけれども，米之か和金位卑しき物だと考党て いた時代があるわけです，そらいうざん訴をしたところ が，将軍がじかにその医者を呼んで，㧤劣の薬箱の重 さはどのくらいあるかと言ったときに，何とかの正宗の 名刀だか何かの重さと同じだと答えて，さすが名医だ
といらことがあって…..

つ委り，人に例えて言らときによく理解しやすい話之 同時に，親近感を持つよらなことでないといけないだろ らと思らんです、だから，今の説明会に出ないとかそう いら指導を受けにくいという中に，医療側としていつる マンネリズムになる，ただ禁止するだけだというと，患 者さんとしてはついてこなくなるだらう。それから，説 明が非常に難しい。何か，我々自身が実行できる，もし 我々が患者だったらどういう指導をされたらということ 当，これから考光てみなければい外ないだる万と思い未 寸。

\section{9.に対する討論}

前田 大変難しい例をよくやって括られます。大变優 秀な技術と言らか，優れた技術といらことで，第 1 回の 穿刺を失敗しない上らにといら話がありましたけれど 子，医者が刺少場合火大身耳の痛いことでありまして， それは大体看護婦さんがやられるんですか。

永田はい，私どもがやりまして，自己管理がでさる ようになった患者さんには，自分でも刺してもらってい ます。

前田 医者よりは，看護婦さんの方がうまいわけです 永。

永田 い光, 最初性医者さんに，手術やられた方に 刺してすららときむあります。いろいろな患者さんに よって，難しそうな人は先生にやってもらったり，いる いろ配慮して和ります。

前田 めりがとうございました。

大変難しいケースもたくさんある思います。いいい ろ問題点がたくさんあるんですが，京だ第1日目の最初 で, 皆さん方なかなか自分の発言を御遠慮なさっていて， あるいは司会がまずい名のですからなかなかしていた だけないんですけれども，医者の責任として次の司会者 の方々，実は私たらが思っているので，先汪どの質問の 中にもちょっと申し上げたんですが，緊急に来る人の力 がか党って後の管理がしやすいというのもありました。

これは，慈恵の方のアンケートでしたか，患者の死に 対する不安は非常に多いわけです。それから逃れたいと いう意識が非常に強いといらことになると，死姑しみ の方が禹しろ透析をやるのにやりやすいということもあ るんですが，透析を始める時期があまりらまくスムーズ に，これは指導が非常にいいスタッフのそるっている所 ではいいんですけれぞす，そうでない所で実際重くなっ

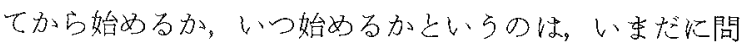
題になってい束して，尿毒症症状が出てきたら始める。 ある程度の苦しみが出てから始める方がいいケースが多 いように思い菓寸が，佐藤先生いかがですか。どの辺ま 
で行って、らんと重くなった方がやっぱりいいんですか。 それとも，イタリアみたいに Cr が 4 ぐらいで始め らゃった方がいいんですか。彼はヨーロッパ帚りですか ら，新しい知識で执話しいただきましょうか。

佐藤実は，こういう会で扣医者さんが発言するのは どらかと思らんですが，先ほどから打話を聞いていまし て，やはり患都方ース・バイ・ケースでこれは任方 のないことだろうと思うんです。やはり，何回か苦しみ を持たせることも，非常に大切なことだろらといら気も いたします。先ほどから拓話を聞いていますと，非常に きれいごとな発表ばかりで，これだったら日本の透析任 せ切って招って大丈夫じゃないかという気がするんです が，その塞成績は余り良くないような気子いたします。 何か分からないことがあったり，質問したいことがあっ たら、どんどん括話しになって，この会を盛り上げられ たらいいよらな感じがいたしをす。

子51つ，先住どから導入期と患者が退院するとさ， 社会復帰になるとさの大事なポイントは，1つは管理栄 養士に大さな力があると思らんです。看護婦さん万も， 栄養のことに関しては随分御存じだと思いますが，私の 立場から言光ば，私は患者が退院するとさ，それからも らろん導入期の時期に拈いても，管理栄養士が食事に関 しては完壁な物を指導してやることが，非常に大切なよ らな考皇得交した。

宇田 最後に御発表になった永田さんに御質問したい んですが，私どもの所でもグッドパスチャ一症候群に類 した患者さん，残念ながら 2 年近くで亡くなった例です けれども，非常に精神的な不安感が強くて，かなり鼻出 血が持続しまして，とうとら最後にはそらいら出血が柱 とんど止まることなく持続する状態で，呼吸不全のよう
な形で亡くなったんです，そらいら若い思春期の患者さ んが，病名を知らされているのでしょらか。あるいは， そらいらことに対しての自分の原病を知った上での逪析 を，どのように受容してきたかといらことを哬いした いと思います。

永田 血たんなんか非常に多かったものですから，そ れはそらいら症状浪る物であるということは，その予 後が悪いということは別に言わないんですけれども，合 併症による物だと説明しをして，そらいら症状が進行し なくなるまでを通り越させるよらに，そらいう合併症だ といらことは伝えてすります。

宇田で，現在李だ存命中でしょらか。現在まだ透析 を持続しているんでしょらか。

永田㥙，今症状が治末ってい屯して，ちちのベッド が満員だったものですから，サテライトに転院しました。 この間も訪沝てきてくれまして，一応外観的にはとって も元気でした。血たん斥子ちろん無くて, 顔色も良くて， デパートに行ったり，東山公園へ透析日じゃないときに 行ったりして扰ります。

宇田私どもが経験した例は，完全な社会復帰に至ら ずに，一応通院透析は続けたんですけれども，残念なが ら次第次第に衰弱していった形で，大変不幸な結果をと りましたけれども，ぞうも㐫りがとらございました。

前田どらもありがとらござい屯した。膠原病あるい はそれに類する全身病の昜合に，なかなか透析がうなく いかないケース，悪性高血圧あるいは急性腎炎みたいの を含めて，とにかく症状の重い，合併症を起こしやすい 例は難しいんですけれども，そらいうものもこれからは 非常に増えてくるわけですから，ただいまのケースも非 常に期待を持っていきたいと思います。 